\title{
消費者の購買地選択行動における選択肢集合の形成方法 THE METHODOLOGY OF CHOICE SETS GENERATION IN CONSUMER CHOICE BEHAVIOR
}

\author{
櫻 井 雄 大* \\ Takehiro SAKURAI
}

\begin{abstract}
This paper proposes the methodology to define choice sets in consumer choice behavior. The classic models such as the Huff model and the Multinomial Logit model are based on the strong assumptions. The representative assumption is that all individuals have the same choice set with all alternatives. However this assumption that used to be put lacks reality. The set of individuals should be different from each other because individuals have limited information about alternatives. The representative extended classic model in the previous papers is the Nested Logit model that considers multi-steps choice structure and similarities between alternatives. However, in the case of consumer behavior, the number of alternatives in the choice set is too large to calibrate models. Therefore the easy way to generate reasonable and manageable choice set is required in order to practical specification. We thus discuss with respect to spatial choice behavior and propose the brief methodology to generate plausible consumers sets. Then we make sure the accuracy of the proposed models comparing with the previous model by applying models on Tokyo area.
\end{abstract}

\author{
Keywords : Consumer, Multinomial Logit Model, Choice Set \\ 消費者，多項ロジットモデル，選択肢集合
}

\section{1. はじめに}

本論文は，消費者の購買行動における選択肢集合の形成方法を提 案し，これを消費者の選択行動モデルに導入して東京都区部に適用 することでその形成方法が適正であるか否かを検証するものである. 消費者の選択行動モデルを構築するにあたり，選択肢集合を用意す ることは必要不可欠である。これまでに多くの研究の蓄積がある離 散選択モデル，特に MNL モデル 1)や八フモデルでは，選択者は全 て同じ選択肢集合を保有しているとされ，選択肢に対する完全情報 という強力な仮定が前提にある。この仮定は選択する対象や分析範 囲によって妥当であるかどうかを判断するべきであり，購買地を対 象と寸る場合，選択者は不完全情報下であると考えるのが自然であ るため，特に緩和されるべきものである.

選択モデルに関する既往研究において，選択の対象は経路や居住 地，購買地など多岐に渡っているが，どのような対象においても選 択肢集合の設定は課題とされている. 課題に対する解決方法として, 特にみられる方法は, Manski ら 2)や Spiggle ら 3)をはじめとする多 段階の選択構造の導入である. 端的には, 第一段階として全選択肢 を要素とする集合から部分集合をア・プリオリに決定する．この部 分集合が選択者の選択肢集合であり，この集合から第二段階として， 最終的な選択をするというものである。 また，決定論的なアプロー チではなく, 確率論的な多段階選択構造を導入したものとして,
Ben-Akiva 4 ,5) らの研究があり，一般に NL モデルと呼ばれている. NL モデルは, MNL モデルを拡張した選択行動モデルで, 全選択肢 に対して類似性の高い選択肢をネスト（部分集合）で分割し，ネス 卜選択とネス卜内の要素選択を段階的に扱うモデルで，経路選択問 題などにおいて多用されているが，選択者は完全情報下であること

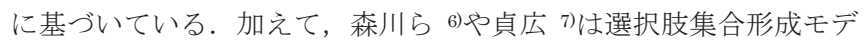
ルを提案している。適用対象は観光地や購買地の選択問題であり, 多段階的な選択肢集合の形成を前提として, 補償型モデルと非補償 型の 2 つのモデルについて言及している．補償型は選択肢の属性を 個別評価するもので，非補償型は総合評価するものである。ここで は，非補償型モデルの方が説明力を有すると結論づけている，これ らのモデルは確率的なもので, 選択肢までの距離と選択肢の魅力度 を統一的に扱っている．上述の既往研究は選択肢集合をモデル上に 反映しているが，選択者の行動原理から導出したものではない.

以上を鑑みて，選択者が不完全情報下であることを前提とした選 択肢集合やその地理的差異については研究の余地が残されている. 本論文では，選択者は不完全情報であることを前提としながら，選 択者が認識しているであろう，尤もらしい集合の形成論理を選択者 の行動原理によって説明し，MNL モデルの拡張を図る.

第 2 章では，既往モデルとして MNL モデルを紹介し，購買地の 属性を考慮したモデルを構築する，第 3 章では，消費者の購買行動

* 東京理科大学工学部建築学科 助教.工博

Assist. Prof., Dept. of Architecture, Tokyo University of Science, Dr.Eng. 
における選択肢集合の形成方法について述べ，続く第 4 章では，選 択肢集合を考慮した選択行動モデルを，東京都区部を対象にして統 計的に推定し, 選択肢集合を考慮したモデルを検証する.終章では, 本研究で得られた知見をまとめ, 今後の課題を述べる.

\section{2. 消費者の選択行動モデル}

消費者の選択行動モデルに関する既往研究は多くの蓄積があるが, そのなかでも最も多用されている MNL モデルを本論文の基礎モデ

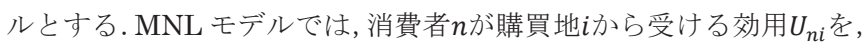
観測者の観測できる確定的効用 $V_{n i}$ と, 観測者の観測できない不確定 的効用 $\varepsilon$ の線形和で表現する :

$$
U_{n i}=V_{n i}+\varepsilon
$$

確定的効用 $V_{n i}$ は一般的に購買地の規模 $S_{i}$, 寸なわち床面積と距離 $d_{n i}$ を説明変数とする関数で表現する. 床面積が大きければ品揃えが多 く, 消費者が受ける効用が増し, 距離が長ければ効用は減じると考 えられるため, 既往研究では, 確定的効用を $V_{n i}=\alpha \ln S_{i}+\beta d_{n i}$ と設 定するものが多い. 尚, $\alpha, \beta$ は規模パラメーター $(\alpha>0)$ と距離パラ メーター $(\beta<0)$ である. ここで, 消費者はより高い効用を得る購買 地を選択し, さらに不確定的効用 $\varepsilon$ が独立で同一なガンベル分布に従 うと仮定すると, MNL モデルが簡潔な式で導出される：

$$
P_{n i}=\frac{e^{V_{n i}}}{\sum_{k \in C} e^{V_{n k}}}, i \in C
$$

ここに，Cは選択肢集合を表す，一般的な MNL モデルでは消費者 $n$ によらず選択肢集合が同一，つまり全ての消費者は集合Cの要素全 てに対し完全情報下であるという仮定に基づいている.

ここで後の選択肢集合の議論のために MNL モデルを拡張する ${ }^{8}$. 一般的な MNL モデルの確定的効用 $V_{n i}$ には, 購買地の総規模 $S_{i}$ を説 明変数として設定しているが, 購買地の性質・性格のようなものを 考慮し, 購買地の属性をMNL モデルに導入する。ここで, 購買地 の属性とは店舗の種類等を示し, それらは購買地の性質・性格を形 成する一要因である. 購買地 $i$ は属性の集合 $A_{i}=\{1,2, \cdots n\}$ を有し, 各属性の規模を $s_{i a}$ と表記する。ここで， $S_{i}=\sum_{\boldsymbol{a} \in A_{i}} s_{i a}$ を満足する. 購買地の属性を考慮した確定的効用 $V_{n i}$ をより詳細に表現すると,

$$
V_{n i}=\sum_{a \in A_{i}} \alpha_{a} \ln s_{i a}+\beta d_{n i}
$$

となり, 既往研究における確定的効用 $V_{n i}$ の規模項 $\alpha \ln S_{i}$ を属性規模 に分解したものであるが，各属性り゙うしは乗法的作用がはたらいて いると仮定している.

\section{3. 選択肢集合の形成方法}

前章で取り上げた MNL モデルは多様な購買行動を平準化したモ デルであり, 分析の対象となる領域が大きいほどその効力を発揮し やすい. 小さな領域では, 多様な購買行動が色濃く反映されてしま い購買行動の推定精度が誤差範囲に納まらないためである。しかし ながら, 相反して, 大規模な範囲になれば消費者の完全情報保有と いう仮定が現実的ではなくなる，大規模領域，例えば東京都区部等 を対象に分析する際，領域にちらばる消費者が同一の選択肢集合を 保有すると仮定するのは無理があり，東京の西に居住する消費者が 東に点在する購買地を選択する可能性は，その認識性を考えても極 めて低い，そこで，従来据えられてきた消費者の全選択肢の完全情
報という強力な仮定を緩和寸る必要があり, 領域内のどの購買地が 消費者にとって選択するに足るか否かを判断するための方法論を用 意しなければならない.

選択者の選択行動は確定的効用の関数で明示的に記述されている (式 (3)). そして, この関数は選択肢の規模と選択肢までの距離で 表現されている，同等の規模でかつ同じ性質・性格を有する二つの 選択肢があり,一方は選択者の近傍にあり, 他方は遠方にある場合, 遠方にある選択肢は選択対象に入らないと考えられる.なぜならば, 選択肢から同等の効用を得るのであれば，遠方の選択肢は選択寸る に足らないと考えられるためである。ただし, 遠方の選択肢が近傍 の選択肢よりも規模が大きいとき，選択対象になるだろう.

対象領域に存在する選択肢 $i$ の集合を $C$ とすると, 消費者 $n$ の選択 肢集合 $T_{n}$ は, $T_{n} \subseteq C$ を満たす.選択肢集合 $T_{n}$ は選択者 $n$ が存在する地 点と, 選択肢 $i$ の規模 $S_{i}$ に依存していると考えられる. 選択肢 $i(i \in C)$ よりも選択者 $n$ に近い位置に存在する選択肢 $j$ の集合を,

$$
\begin{aligned}
C_{n i}{ }^{\prime}:= & \left\{j \mid d_{n i}>d_{n j}\right\} \\
& i \notin C_{n i}{ }^{\prime} \\
& \phi \in C_{n i}{ }^{\prime} \\
& C_{n i}{ }^{\prime} \subseteq C
\end{aligned}
$$

とすると, 選択肢集合 $T_{n}$ に含まれる選択肢は,

$$
T_{n}:=\left\{i \mid S_{i}>S_{j}\right\}
$$

であり, 論理式(5)は, 選択肢 $i$ の規模 $S_{i}$ が選択肢 $i$ より選択者に近い 全ての選択肢 $j\left(j \in C_{n i}{ }^{\prime}\right)$ の規模 $S_{j}$ よりも大規模である場合に選択肢 $i$ を選択肢集合 $T_{n}$ に含むとするもので，選択肢集合を決定論的に形成 するための論理である，消費者は近傍で，また大規模な購買地を選 択するという性質を論理形式にしたものである.この論理上の行動 原理として,

$$
\begin{gathered}
\left\{i \mid \max S_{i}, i \in C\right\} \Rightarrow i \in T_{n}, \forall n \\
\left\{i \mid \min d_{n i}, i \in C\right\} \Rightarrow i \in T_{n}
\end{gathered}
$$

$\left\{i \mid d_{n i}>d_{n k}, \max S_{k}>S_{i}, i, k \in C\right\} \Rightarrow i \notin T_{n} \quad$ 性質(3) が挙げられる。性質(1)は, 領域内で最も大規模な選択肢iは全ての 選択者の共通の選択肢として含まれることを示す, つまりは, 最大 規模の購買地の顧客居住範囲は，消費者が存在する地点に関係なく 対象領域全てである。性質(2)は，消費者 $n$ に最も近い選択肢 $i$ はの 消費者の選択肢集合 $T_{n}$ に含まれ, 購買地 $i$ の顧客居住範囲がその近傍 に存在することを示す，性質(3)は，最大規模の選択肢 $k$ よりも遠い 地点に存在する選択肢 $i$ は選択肢集合 $T_{n}$ に含まれないことを示し，最 大規模を有する購買地よりも遠い地点で消費者は購買行動をしない ということである.

性質(3)は強力な仮定であり，現実とかけ離れた選択肢集合になる おそれがある。そこで，論理式(5)を発展させ，性質(3)を緩和する必 要がある. 性質(3)の緩和には選択肢の属性を導入することで解決で きる，前章で取り上げた選択肢の属性は，性格・性質のようなもの であるから，ある属性 $a \in A_{i}$ が突出して大規模であれば，選択者の 選択肢になり得る. 論理式(5)の規模を属性規模として考えると以下 の論理が導かれる。

$$
\begin{gathered}
T_{n}:=\left\{i \quad \exists a, s_{i a}>s_{j a}\right\} \\
a \in A_{i} \\
j \in C_{n i}{ }^{\prime} \\
\left\{i \mid i \in C \wedge i \notin C_{n i}{ }^{\prime}\right\}
\end{gathered}
$$



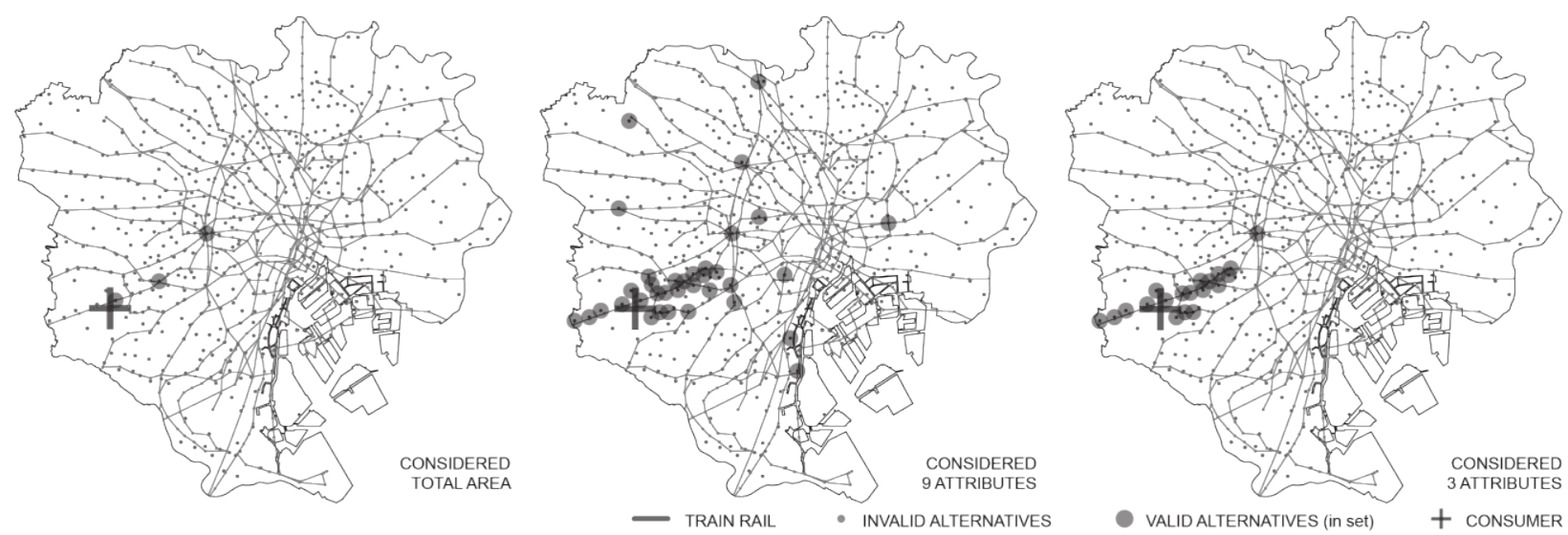

Fig.1 The Distributions of Alternatives in 3 Types of The Choice Set

論理式(5)’は，選択肢 $i$ の属性規模 $s_{\boldsymbol{i a}}$ が，選択肢 $i$ よりも消費者 $n$ に近 い全ての選択肢 $j$ の属性規模 $s_{j a}$ と比較したとき，一つ以上の大きな 属性規模を有する場合, 選択肢 $i$ は選択肢集合 $T_{n}$ に含まれるとみなし ている.ここでは性質(3)が緩和され, 最大規模を有する購買地より も遠い地点の購買地はその属性規模により集合に含まれるかどうか が判断される. 従って, より遠方に存在する総規模が小さい購買地 でも選択肢集合に含まれる可能性があり, 論理式(5)’で判定される集 合の要素数は論理式(5)で判定されるものよりも多くなることは明 らかである. その他, 論理式(5)'の性質は論理式(5)のそれと比較し て，性質(1)は，領域内で最も大きな属性規模を有する選択肢 $i$ 全 ての選択者に共通の選択肢として選択肢集合 $T_{n}$ に含まれ，性質(2)は 論理式(5)'の性質として同样にしてある.

Fig. 1 は東京都世田谷区経堂 5 丁目に存在する消費者の選択肢集 合で，上述の論理を適用したものであり，有効な購買地は小田急線 沿線に分布している注 1). 属性は商業統計の業態別の分類注 2) に準じ ている. Fig.1の左から, 総規模, 全 9 属性, 3 属性（属性 $1,7,8 ）$ を考慮したものであり，属性数が多くなるにつれて有効な選択肢が 増加する．直感的には 3 属性を考慮した選択肢集合が最も現実を表 現していると思われ，属性の定義如何により現実的な選択肢集合を 表現できるかどうかが左右される.

次に，消費者の周遊選択行動に言及する，周遊選択行動とは，消 費者が一度の購買行動で周遊的に複数の購買地を選択寸ることであ る. 周遊選択肢を考慮すると一般に組み合わせによる膨大な選択肢 の数になり現実的ではなくなる.この点においても決定論的に事前 に選択肢集合を用意することは重要である。ここで，高々二つの購 買地を周遊選択寸ると仮定する. 選択肢集合には単一選択肢 $\{i\} \subseteq T_{n}$ と周遊選択肢 $\{i, j\} \subseteq T_{n}$ があり，周遊選択肢 $\{i, j\}$ が選択肢集合に含ま れる必要条件は単一選択肢 $\{i\},\{j\}$ の双方の確定的効用よりも大きく なければならないと考えるのが自然である. 従って, $V_{n\{i, j\}} \geq V_{n i} \wedge$ $V_{n\{i, j\}} \geq V_{n j}$ を満足する. ここで, 周遊選択行動における確定的効用 $V_{n\{i, j\}}$ を,

$$
V_{n\{i, j\}}=\sum_{a \in A_{i}} \alpha_{a} \ln \left(s_{i a}+s_{j a}\right)+\beta\left(d_{n i}+d_{i j}+d_{j n}\right)
$$

と定義する，距離項は全トリップ長を表し，単一選択の場合は，往 復の距離として計算する。式（6）は，消費者が選択肢 $i, j を$ 周遊選 択するときに得る効用と, 購買地 $i, j$ を統合した仮想的な単一選択肢
が周遊距離と同じ距離にある場合に得る効用が同等であると仮定し ている，仮想的な単一選択肢として置換できれば，選択肢集合を形 成するための論理式(5)'を適用することが可能で, 周遊選択肢を考慮 した選択肢集合を定義することができる.

この章の最後に消費者の選択肢集合の魅力度を定義する. 選択肢 集合の魅力度については, Fotheringham ${ }^{8)}$ が言及している。これ より以降は Fotheringham に倣う。選択肢がそれぞれ独立に魅力度 を持っているとすると，その集合の魅力度は，

$$
V_{n T_{n}}=f\left(\sum_{i \in T_{n}} V_{n i}, \gamma\right)
$$

と定義できるだろう。ここに, $\gamma$ はパラメーターである.関数 $f(\cdot)$ を 具体的に指数関数で定義すると,

$$
V_{n T_{n}}=\left(\sum_{i \in T_{n}} V_{n i}\right)^{\gamma}
$$

となる. 確定的効用 $V_{n i}$ の総和が大きくなれば選択肢集合の魅力度 $V_{n T_{n}}$ は大きくなるが，その増加率は確定的効用 $V_{n i}$ の総和が大きけれ ば大きいほじ減少するだろう. 従って, パラメーター $\gamma$ は $0<\gamma<1 の$ 範囲が適切である。

\section{4. モデルパラメーターの推定とモデルの比較検証}

ここでは, 第 2 章において構築している消費者の選択行動モデル

Table 1 Estimated parameters (Model 1,1-S)

\begin{tabular}{cccc}
\hline \hline & Model 1 & & Model 1-S \\
$\alpha$ & 0.6429 & 0.6802 \\
$\beta$ & -0.2332 & & $(121.0970)$ \\
$(-256.8372)$ & & -0.2805 \\
$(-185.1578)$ \\
$\operatorname{LL}(\mathbf{0})$ & -166104.60 & & -81740.50 \\
$\operatorname{LL}(\alpha, \beta)$ & -78029.9 & & -47180.180 \\
$\rho^{2}$ & 0.5302 & 0.4228 \\
BIC & 156080.20 & \\
Ratio of Fitness & 0.6296 & 94380.470 \\
\hline \hline
\end{tabular}

* (.) shows t-statistics 
のパラメーターを統計的に推定し，既往モデル（MNL モデル）と 選択肢集合を考慮した選択行動モデルとの比較検証を行う。対象範 囲は東京都区部注3) とし, 平成 20 年度のパーソントリップデータ (以下，PT データ）と平成 19 年度の商業統計業態別統計編を用い てモデルパラメーターを推定する。商業統計注2)には, 購買地の属 性毎の売場面積が記載してあり，全 9 属性の分類である。それらの 属性をもとに類似している属性をまとめて全 5 種の改変した属性分
類も用意する.モデルの規模項には売場面積が変数として入力され, 距離項は時間距離注 1) とし, 購買地まで最短時間で到達する経路を 利用すると仮定する.

推定方法は最尤法（数值計算は準ニュートン法）で, 推定值を検 証するための諸統計量として, $t$ 值（推定值の統計的有意性を示し， $t$ 值が 1.96(2.576)以上で $5 \%(1 \%)$ 有意であると判断する), 初期対数 尤度 $\operatorname{LL}(\mathbf{0})$, 最終対数尤度 $\operatorname{LL}(\alpha, \beta)$, 尤度比 $\rho^{2}$, BIC, 適中率（推定さ

Table 2 Estimated parameters (Model 2)

\begin{tabular}{|c|c|c|c|c|}
\hline & Model 2 & $\begin{array}{c}\text { Model } 2 \\
\text { (excluding parameter } \alpha_{8} \text { ) } \\
\end{array}$ & & Model 2' \\
\hline$\alpha_{1}$ & $0.702(33.2455)$ & $0.703(33.9315)$ & $\alpha_{1}^{\prime}$ & $0.0697(33.8575)$ \\
\hline$\alpha_{2}$ & $0.0293(14.1880)$ & $0.0294(14.3908)$ & $\alpha_{2}^{\prime}$ & $0.0289(14.2000)$ \\
\hline$\alpha_{3}$ & $0.0417(13.4761)$ & $0.0417(13.4809)$ & $\alpha_{3}^{\prime}$ & $0.0431(14.2888)$ \\
\hline$\alpha_{4}$ & $0.0327(5.2730)$ & $0.0325(5.2715)$ & $\alpha_{4}^{\prime}$ & $0.2087(22.2994)$ \\
\hline$\alpha_{5}$ & $0.0259(5.8409)$ & $0.0260(5.8670)$ & $\alpha_{5}^{\prime}$ & $0.3281(30.8366)$ \\
\hline$\alpha_{6}$ & 0.1306 (19.7629) & $0.1308(19.8823)$ & & \\
\hline$\alpha_{7}$ & $0.2732(18.6130)$ & $0.2765(26.8472)$ & & \\
\hline$\alpha_{8}$ & $0.0029(0.3118)$ & $-(-)$ & & \\
\hline$\alpha_{9}$ & $0.0393(7.3102)$ & $0.0392(7.3196)$ & & \\
\hline$\beta$ & $-0.2333(-256.7135)$ & $-0.2333(-256.7165)$ & $\beta$ & $-0.2332(-256.3675)$ \\
\hline $\operatorname{LL}(\mathbf{0})$ & -166104.60 & -166104.60 & $\operatorname{LL}(\mathbf{0})$ & -166104.60 \\
\hline $\operatorname{LL}(\alpha, \beta)$ & -78263.910 & -78263.960 & $\operatorname{LL}(\alpha, \beta)$ & -78174.70 \\
\hline$\rho^{2}$ & 0.5288 & 0.5288 & $\rho^{2}$ & 0.5294 \\
\hline $\mathrm{BIC}$ & 156629.80 & 156619.70 & $\mathrm{BIC}$ & 156410.60 \\
\hline Ratio of Fitness & 0.6631 & 0.6627 & Ratio of Fitness & 0.6339 \\
\hline
\end{tabular}

* (.) show t-statistics

Table 3 Estimated parameters (Model 2-S)

\begin{tabular}{|c|c|c|c|c|}
\hline & Model 2-S & $\begin{array}{c}\text { Model 2-S } \\
\text { (excluding parameter } \alpha_{8} \text { ) }\end{array}$ & & Model 2'-S \\
\hline$\alpha_{1}$ & $0.721(28.3160)$ & $0.726(28.3160)$ & $\alpha_{1}^{\prime}$ & $0.0689(25.6599)$ \\
\hline$\alpha_{2}$ & $0.0217(9.1680)$ & $0.0220(9.1680)$ & $\alpha_{2}^{\prime}$ & $0.0215(8.7152)$ \\
\hline$\alpha_{3}$ & $0.0271(7.7501)$ & $0.0272(7.7501)$ & $\alpha_{3}{ }^{\prime}$ & $0.0268(7.5436)$ \\
\hline$\alpha_{4}$ & $0.0613(8.5079)$ & $0.0604(8.5079)$ & $\alpha_{4}{ }^{\prime}$ & $0.2694(22.5245)$ \\
\hline$\alpha_{5}$ & $0.0269(5.2244)$ & $0.0272(5.2244)$ & $\alpha_{5}{ }^{\prime}$ & $0.3217(25.3313)$ \\
\hline$\alpha_{6}$ & $0.1160(15.9843)$ & $0.1167(15.9843)$ & & \\
\hline$\alpha_{7}$ & $0.3161(18.5458)$ & $0.3309(18.5458)$ & & \\
\hline$\alpha_{8}$ & $0.0131(1.2126)$ & $-(-)$ & & \\
\hline$\alpha_{9}$ & $0.0394(6.3952)$ & $0.0384(6.2931)$ & & \\
\hline$\beta$ & $-0.2797(-184.0813)$ & $-0.2797(-184.1326)$ & $\beta$ & $-0.2943(-170.3078)$ \\
\hline $\operatorname{LL}(\mathbf{0})$ & -81740.50 & -81740.50 & $\operatorname{LL}(\mathbf{0})$ & -69187.780 \\
\hline $\operatorname{LL}(\alpha, \beta)$ & -47390.650 & -47391.370 & $\operatorname{LL}(\alpha, \beta)$ & -40326.780 \\
\hline$\rho^{2}$ & 0.4202 & 0.4202 & $\rho^{2}$ & 0.4171 \\
\hline $\mathrm{BIC}$ & 94881.870 & 94873.240 & $\mathrm{BIC}$ & 80713.60 \\
\hline Ratio of Fitness & 0.6770 & 0.6770 & Ratio of Fitness & 0.7078 \\
\hline
\end{tabular}

* (.) show t-statistics 
れたモデルで最も高い確率を示す購買地と $\mathrm{PT}$ データとの一致の度 合い）を共に計算している.

選択行動モデルは次の 4 つを用意する.

Model 1： 既往モデル（MNL モデル）で, 確定的効用 $V_{n i}$ の規模項 を購買地の総規模としたもの注4).

Model 2： 購買地の属性を考慮した MNL モデルで, 確定的効用 $V_{n i}$ を式(3)で表現したもの注4).

Model 1-S :モデル 1 に対して選択肢集合を考慮したもの.

Model 2-S :モデル 2 に対して選択肢集合を考慮したもの.

Model 2 及び Model 2-S は 2 種類の属性分類を適用し， 2 つのモデ ルを推定する。

Table 1 は Model 1 及び Model 1-S の推定結果で，全てのパラメ 一ターについて $1 \%$ 有意に推定されている。適中率の観点からは選 択肢集合を考慮したモデルの方が高い説明力をもつことがわかる.

Table 2,3 に Model 2 と Model 2-S の推定結果を示す. いずれの モデルにおいても属性 8 (中心店) が有意に推定されていないため,
属性 8 を除外して推定している. 除外した後の他のパラメーターを みると, 推定值にほぼ変化がみられないため, 属性 8 は選択行動に 対し非常に小さな影響であると考えられる. 改変した属性分類では 全てのパラメーターについて有意に推定されている. 距離パラメー ター $\beta$ Model 1 群においても同様に，選択肢集合を考慮した方が 小さな值になっている。これは，標本サンプルの選定，つまり選択 肢集合の決定によるところが大きいと考えられ，例えば，東に居住 する消費者が西の小さな購買地に出向しているノイズのような標本 サンプルは選択肢集合に含まれないため, データ上では削除されて いる. 端的には, 距離摩擦が効いていない標本サンプルは選定され 難いためである。総じて，全てのモデルにおいて，選択肢集合を考 慮したモデルの方が既往モデルと比較して適中率が上がっている.

特に, Model 2'と Model 2'-S の適中率は 7\%ほど上がり, 大きな精 度向上といえるだろう。

次に東京都区部の選択肢集合の魅力度の分布について言及する. Fig. 2 に選択肢集合の魅力度の分布を示す. 選択肢集合の魅力度は

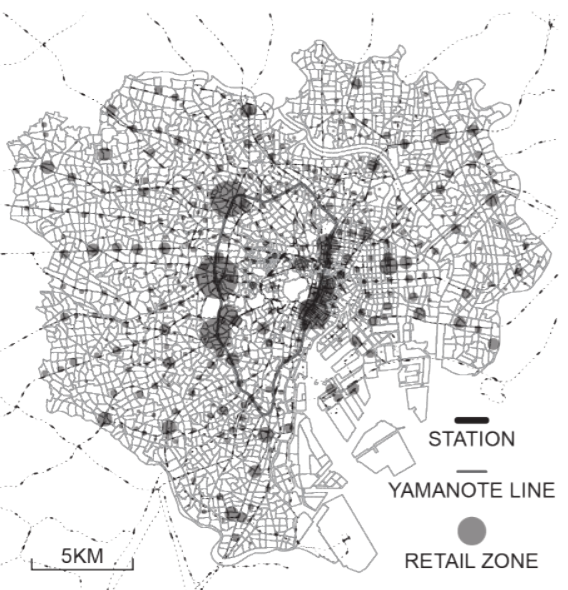

(a)

Distribution of retail area in Tokyo

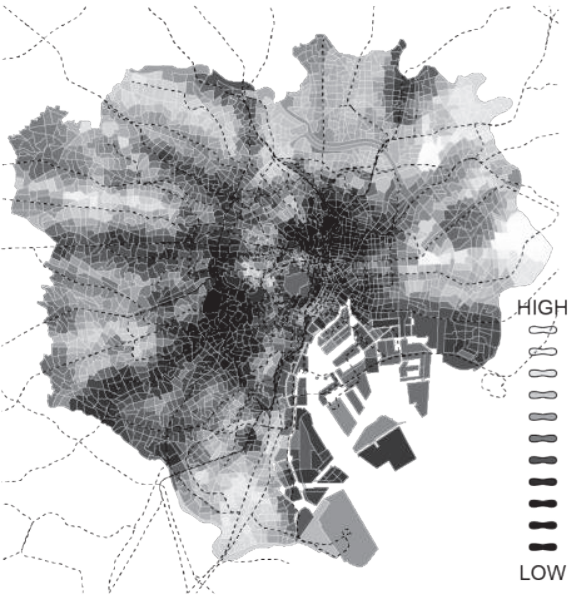

(b)

Distribution of sum of attractiveness $\sum_{i \in T_{n}} \ln S_{i}$ in set $T_{n}$

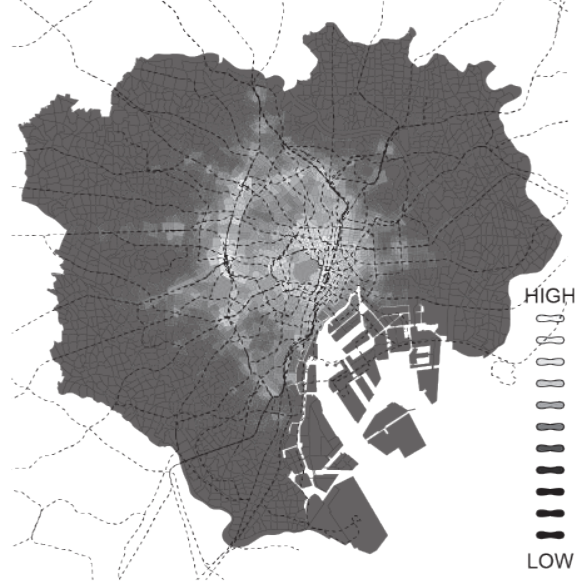

(c)

Distribution of attractiveness $V_{n c}$ using estimated parameters in Model 1

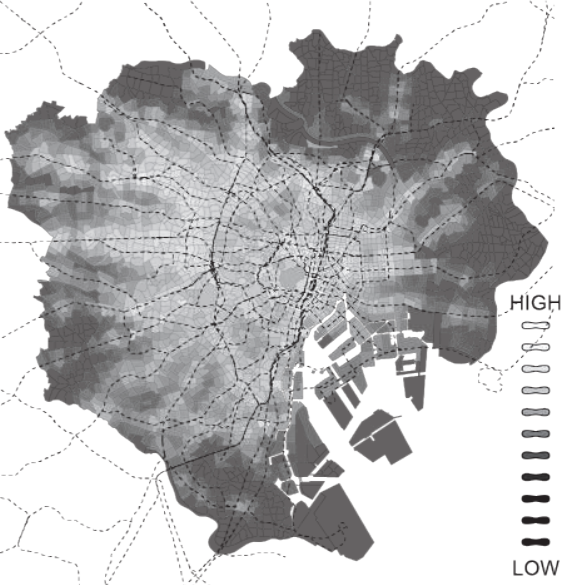

(d)

Distribution of attractiveness $V_{n T_{n}}$ using estimated parameters in Model 2'-S

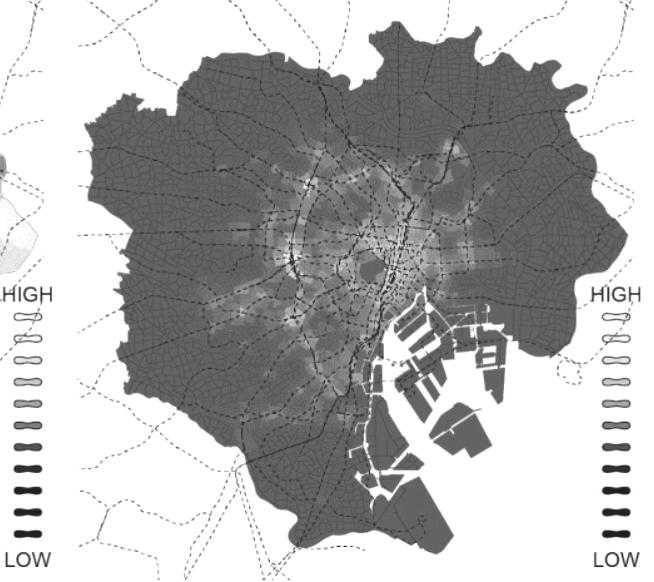

(e)

Distribution of attractiveness $V_{n C}$ on the condition $V_{n i} \geq 0$ using estimated parameters in Model 1

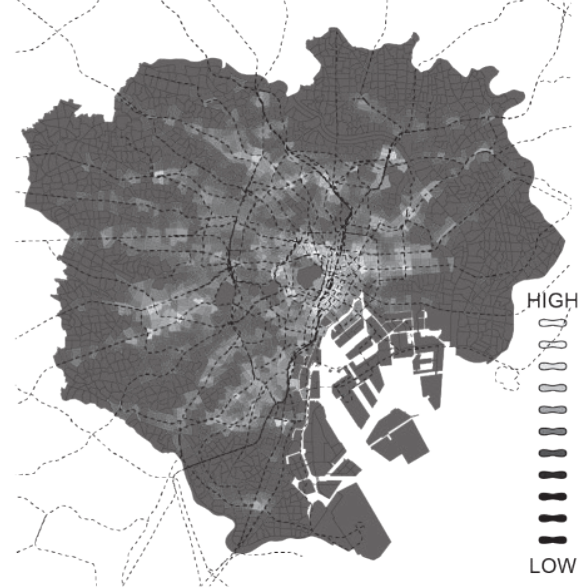

(f)

Distribution of attractiveness $V_{n T_{n}}$ on the condition $V_{n i} \geq 0$ using estimated parameters in Model 2'-S

Fig.2 The Distribution of Attractiveness of The Choice Sets 
式(8)で定義したとおりである. Fig. 2 (b)は，選択肢集合に含まれる 購買地のみの対数化した規模を総和したもの $\left(\sum_{i \in T_{n}} \ln S_{i}\right)$ で, 距離 摩擦を考慮していない魅力度である。山手線沿線上は選択肢集合の 魅力度が小さく，その内側と外側が高くなっている. 山手線上の駅 は多くの鉄道路線が交差しているため, どのような購買地に対して も大きな距離摩擦がなく出向でき, 最大規模を有する新宿駅周辺の 購買地が時間距離にして近い. 従って, 山手線沿線上では選択肢集 合の要素数が少なく，東京都区部の周縁では要素数が多い．Fig. 2 (b)に対して距離摩擦抵抗を考慮した分布が(c)-(f)であり，既往モデ ルと提案モデルの両方を示している. Fig. 2 (c), (d)は式(8)の定義と おりであるが，Fig. 2 (e)，(f)は式(8)に対して $V_{n i} \geq 0$ を制約条件とし て計算したもので, 距離摩擦よりも大きい規模効用を有する購買地 のみを対象にしている. 遠方にある購買地はその規模が大きいとし ても距離摩擦によって全体で負の確定的効用になるものがあり，こ れを除去したものである，選択肢集合を考慮しない場合，山手線沿 線上が選択肢集合の魅力度が高く, 周縁部に向からに従って魅力度 が低くなってゆく．既往モデルでは全ての購買地を選択肢集合に含 めているため, 周縁部では遠方の購買地による負の確定的効用が大 きく効いている. 従って, 距離摩擦が全体の購買地に対して平均的 で，近傍に大規模の購買地がある山手線沿線の魅力度が高くなる. 選択肢集合を考慮する場合は，山手線沿線に限らず鉄道路線上でほ ぼ全てにおいて高い魅力度を有している。これは遠方の小さな購買 地が選択肢集合に含まれていないため,負の確定的効用 $V_{n i}$ が少ない ことに起因する.

選択肢集合の魅力度は, 集合に含まれる要素数と距離摩擦によっ て決定される．要素数が増加すれば集合の魅力度は増すと考えるの が普通であるが，選択肢集合の形成論理において要素数が多いとい うことは最大規模を有する購買地が遠方に存在することを意味する ため, 要素数のみでは魅力度は端的に判明しない. 既往モデルでは, 集合の要素数は地点に依らず一定であるため空間にちらばる購買地 への移動がしや寸い地点において選択肢集合の魅力度が高いことは 自明である。しかしながら，実際は地点によって集合の要素数は異 なると考えるのが自然であり, 集合の魅力度の分布は単純には判明 しない，本論文で得ている Fig. 2 は，選択肢集合の魅力度は空間の 中心部のみが高いという従来の見解とは異なり，鉄道路線などの都 市基盤が有効に働いているならば集合の魅力度は中心部のみならず 周縁も高くなるということを示唆している.

\section{5. 結語}

本論文では, 離散選択モデルのうち, 代表的なモデルとして MNL モデルを基礎モデルとし，これを拡張するかたちで選択肢集合の形 成論理を提案した，既往モデルと提案モデルの比較では，全てにお いて適中率が向上し，選択肢集合を考慮すれば精度向上が見込める ことを示した．提案した選択肢集合の形成方法は，購買地の規模あ るいは属性規模と消費者と購買地との距離により一意に定まるもの として考えて推定に使用する標本データの選定をしているため，モ デルパラメーターの推定に大きな負荷をかけないメリットがある.

また，東京都区部において選択肢集合の魅力度は中心部のみではな く, 周縁の鉄道路線沿線も同様に高いことを示した.

本論文で提案した選択肢集合の形成方法は，分析対象の魅力度と
距離が定義できるならば，購買地ではない他の対象にも容易に適用 することが可能である点において汎用性のあるものと考えられる.

本論文の課題として, 選択肢集合の形成論理を単純明解にする意 図があるものの，選択肢を集合に含む際の評価に確率的なものを考 慮していないことが挙げられる．購買地の規模が大きくなればなる ほど消費者はその正確な規模を把握することができなくなるため, このような事象は確率的に表現するのが適切であると考えられる. 決定論的であり確率的である選択肢集合の形成方法は次なる課題で ある。

\section{参考文献}

1) Train, K. : DiscRETE CHOICE METHODS WITH SIMULATION, $2^{\text {nd }}$ Edition, Cambridge University Press, 2009

2) Manski C. : THE STRUCTURE OF RANDOM UTILITY MODELS, Theory Decision 8, pp.229-254, 1977

3) Susan Spiggle, Murphy A. Sewall : A CHOICE SETS MODEL OF RE TAIL SELECTION, Journal of Marketing, Vol.51, pp.97-111, 1987

4) Ben-Akiva, M.E., S.R. Lerman : DISCRETE CHOICE ANALYSIS : THEORY AND APPLICATION TO PREDICT TRAVEL DEMAND, The MIT press, 1985

5) Joffre Swait, Moche Ben-Akiva : INCORPORATING RANDOM CONSTRAINTS IN DISCRETE MODELS OF CHOICE SET GENERATIN, Transportation Research Part B Methodological Vol.21, Issue 2, pp.91-102, 1987

6) T.Morikawa, H. Takeuchi, Y. Kako : DESTINATION CHOICE ANALYSIS OF REGIONS AND PROBABILISTIC CHOINCE SETS, Japan Society of Civil Engineers,Vol. 9, pp.117-124, 1991

7)Y. Sadahiro : AN EMPIRICAL STUDY OF CHOICE SET IN STORE CHOICE, Urban Planning, Vol.46, pp.57-61, 1997

8) A. Stewart Fotheringham : CONSUMER STORE CHOICE AND CHOICE SET DEFINITION, Marketing Science, Vol.7, No.3, pp.299-310, 1988

9)T. Sakurai, K. Imai : RETAIL TRADE AREA BASED ON CONSUMER BEHAVIOR MODEL : A case study on Tokyo metropolitan area, Journal of Architecture and Planning (Transactions of AIJ), Vol.79, 704, pp.2199-2205, 2014.10 (in Japanese)

注

注1)選択行動モデルにおける距離の計算は, すべて時間距離で計算している. 消費者が存在する地点から最寄り駅までは直線距離（徒歩）で, 購買地 の最寄り駅までは最短時間で到達する経路 (鉄道) とし, 購買地の最寄 り駅から購買地までは直線距離（徒歩）で計算している.

注2)商業統計では,「属性 1 : 百貨店」,「属性 2 : 総合スーパー」,「属性 3: 専門スーパー」,「属性 4 : コンビニエンスストア」,「属性 5 : ド ラッグストア」，「属性 6 : その他のスーパー」，「属性 7 : 専門店」, 「属性 8 : 中心店」,「属性 9 : その他」が定義されている. それぞれの 属性について, セルフサービス方式（属性 $2,3,4,5,6$ が該当）と非セルフ サービス方式（属性 $1,7,8$ が該当）が記載されており，本論文では最寄 品を扱う店舗はセルフサービス方式, 買回品を扱う店舗は非セルフサー ビス方式として解釈している。これらの方式を勘案して再分類したもの が，「属性1'：百貨店」，「属性2'：総合スーパー」，「属性 $3^{\prime}$ : 専門ス 一パー」,「属性 $4^{\prime}$ : 専門店と中心店」（属性 $7+8 ）$ と「属性 $5^{\prime}$ : その 他の属性」（属性 $4+5+6+9 ）$ である。パラメーターの推定では，商業 統計の定義通りの 9 属性と，再分類した 5 属性を採用し，各属性番号は パラメーターの添え字と対応している.

注3) 本研究では対象範囲を東京都区部に限っているため, 都区部外に存在す る購買地の選択肢を考慮していない，東京都区部の行政区域は高速道路 や河川などにより定められているため，空間的に分離しているものとみ なしている.

注4) Model 1,2 は櫻井ら 9) の研究のうちで構築されているモデルで, 推定結果 に関しても同様の值を援用している．使用しているデータや推定方法な ど全て同等であり，モデルの比較に何ら支障はない. 


\section{Takehiro SAKURAI*}

* Assist. Prof., Dept. of Architecture, Tokyo University of Science, Dr.Eng.

This paper discusses choice sets in consumer behavior. We have many works analyzing individual choice behavior. These objectives are path choice, household choice, commercial area choice and so forth. Almost all these works take the way that is to express choice behaviors as a mathematical model to analyze and most works assume individuals with the complete information. The assumption of the complete information is the precondition that all individuals have all information about alternatives and relates deeply to individual choice set. In case that there are a large number of decision-makers and alternatives in the area applied the model, the larger size of the area, the larger size of choice set of decision-maker, the assumption, that is decision-maker with complete information, is not valid and gets unreal.

There are two ways to consider choice sets in previous papers. The first is the way to determine sets a priori and the next is the probabilistic approach. These approaches are considered multi-steps choice structure. That is the choice an alternative from subset continued from the choice a subset from the set of subsets. The deterministic approach considers that the choice set is consist of available alternatives that the decision makers consider actually. There are a few considerations in terms of the methodology of generation of choice set in the papers that take its approach. The another approach is that the choice probability derives from the joint probability that the choice probability of alternative and subset. There is the representative model that is the Nested Logit model described in Ben-Akiva(1985). The choice sets in the NL model are considered similarity in alternatives in the master choice set therefore it is the subset characterized by similarity. It assumes the individuals with the complete information.

In this paper, in the sake of applying the consumer behavior model to a large area such as Tokyo, we at first propose the choice set generation methodology that is deterministic and a priori sets and extend the previous model. The methodology defines the scale of commercial area and distance. The next, we apply the models on Tokyo area and calibrate the models statistically. Then, we assess the proposed model comparing the previous model. Finally, we discuss the distribution of the attractiveness of the choice sets in Tokyo area using the calibrated parameters. 